\title{
Preliminary results on the use of semi-floating shrimp traps for the striped soldier shrimp, Plesionika edwardsii (Crustacea: Decapoda: Pandalidae), off the Algarve coast (southern Portugal)
}

\author{
Moritz Eichert $^{1,2}$, Aida Campos ${ }^{3,1}$, Paulo Fonseca ${ }^{3,1}$, Victor Henriques ${ }^{3,1}$, Margarida Castro ${ }^{1,2}$ \\ ${ }^{1}$ CCMAR, Centro de Ciências do Mar do Algarve, Universidade do Algarve, Gambelas, 8005-139, Faro, Portugal. \\ (ME) (Corresponding author) E-mail: meichert@ualg.pt. ORCID iD: https://orcid.org/0000-0003-3565-1762 \\ (AC) E-mail: acampos@impa.pt. ORCID iD: https://orcid.org/0000-0002-5972-6266 \\ (PF) E-mail: pfonseca@impa.pt. ORCID iD: https://orcid.org/0000-0003-4177-8196 \\ (VH) E-mail: victorh@ ualg.pt. ORCID iD: https://orcid.org/0000-0002-0894-3543 \\ (MC) E-mail: macastro@ualg.pt. ORCID iD: https://orcid.org/0000-0002-7860-2074 \\ ${ }^{2}$ FCT, Faculdade de Ciências e Tecnologia, Universidade do Algarve, Gambelas, 8005-139, Faro, Portugal. \\ ${ }^{3}$ IPMA, Instituto Português do Mar e da Atmosfera, Rua Alfredo Magalhães Ramalho, 6, 1495-006 Lisboa, Portugal.
}

\begin{abstract}
Summary: The present study provides an account of an experimental survey aiming at the evaluation of the catchability of the striped soldier shrimp, Plesionika edwardsii, using semi-floating shrimp traps off the Algarve coast (southern Portugal). Currently, this species is not targeted by the crustacean bottom trawl fleet, and preliminary results on product value suggest that this may become an economically viable new fishery. Preliminary results suggest that this fishery could contribute to the diversification of fixed gears of low environmental impact targeting deep-water crustaceans, in agreement with the objectives of both the Marine Strategy Framework Directive and the reformed Common Fisheries Policy. However, potential spatial conflicts with trawling, the unknown size of the resource and a necessary precautionary approach may limit the number of licences that can be granted.
\end{abstract}

Keywords: semi-floating shrimp traps; crustacean fisheries; Plesionika edwardsii; southern Portugal.

Resultados preliminares sobre el uso de nasas camaroneras semiflotantes para la pesca del camarón soldado rayado, Plesionika edwardsii (Crustacea: Decapoda: Pandalidae), en la costa de Algarve (sur de Portugal)

Resumen: El presente trabajo proporciona una primera aproximación para la implementación de una pesquería comercial para el camarón soldado rayado, Plesionika edwardsii, mediante el uso de nasas camaroneras semiflotantes en la costa del Algarve (sur de Portugal). Los resultados preliminares obtenidos sobre la capturabilidad y el valor del producto sugieren la posibilidad de convertirse en una nueva pesquería económicamente viable, ya que actualmente esta especie no es objetivo de la flota de arrastre de fondo de crustáceos. Los resultados preliminares sugieren que esta pesquería podría contribuir a la diversificación de los artes fijos de bajo impacto ambiental dirigidos a los crustáceos de aguas profundas, de acuerdo con los objetivos tanto de la Directiva Marco de la Estrategia Marina (MSFD) como de la Política Pesquera Común (PPC). Sin embargo, los posibles conflictos espaciales con la pesca de arrastre, el tamaño desconocido del recurso y un necesario enfoque cautelar pueden limitar el número de posibles licencias de pesca.

Palabras clave: nasas camaroneras semiflotantes; pesquerías de crustáceos; Plesionika edwardsii; sur de Portugal.

Citation/Como citar este artículo: Eichert M., Campos A., Fonseca P., Henriques V., Castro M. 2018. Preliminary results on the use of semi-floating shrimp traps for the striped soldier shrimp, Plesionika edwardsii (Crustacea: Decapoda: Pandalidae), off the Algarve coast (southern Portugal). Sci. Mar. 82S1: 209-214. https://doi.org/10.3989/scimar.04758.02A

Editor: F. Maynou.

Received: January 26, 2018. Accepted: May 28, 2018. Published: July 31, 2018.

Copyright: () 2018 CSIC. This is an open-access article distributed under the terms of the Creative Commons Attribution 4.0 International (CC BY 4.0) License. 


\section{INTRODUCTION}

Worldwide, deep-water crustaceans are commonly captured with trawls, and Portugal is no exception. At present, the Portuguese trawl fleet comprises about 80 trawlers (DGRM 2017), 26 of which are licensed for 55 and/or $70 \mathrm{~mm}$ codend mesh size classes, constituting a distinct fleet component targeting crustacean species. Typically, this fleet segment operates off the south and southwestern Portuguese coasts on muddy bottoms at the edge of the continental shelf and upper slope, at depths ranging from about 150 to $700 \mathrm{~m}$ and deeper (Campos et al. 2007). The main target species are the rose shrimp, Parapenaeus longirostris, which constitutes the bulk of the catches, the Norway lobster, Nephrops norvegicus, and deep-sea shrimps such as the blue and red shrimp, Aristeus antennatus, the scarlet shrimp, Aristaeopsis edwardsiana, and the giant red shrimp, Aristaeomorpha foliacea.

Like many trawl fisheries worldwide, Portuguese crustacean trawling is characterized by considerable amounts of by-catch and discards, including fish, cephalopods and other crustaceans (Borges et al. 2001, Monteiro et al. 2001, Costa et al. 2008). The trawling activity also drives the associated ecosystem into a continuous state of disturbance, resulting in significant impacts on both the faunal composition (Jones 1992, Roberts 2002, Gage et al. 2005) and substrate properties (Martín et al. 2014, Oberle et al. 2015) of the benthic community.

A possible approach to minimizing the amount of discarded by-catch in this fishery is the introduction of gear modifications: by-catch reducing devices (Fonseca et al. 2005, 2007). However, this approach does not address the negative impacts of bottom trawling on the seafloor. An alternative is the progressive substitution of trawls by less impacting gears, providing that the yields of the target species ensure the economic viability of the new fisheries. An example of such a fishery is the trap fishery for the Norway lobster carried out off the western Portuguese coast by multi-gear vessels (Leocádio et al. 2012).

In Portuguese continental waters, the development of commercial trap fisheries targeting deep-water shrimps has not received sufficient attention. However, experimental fishing for benthic and nektobenthic shrimps has been carried out in areas with narrow continental shelves that are inaccessible to trawling. Such is the case of the Azores archipelago, where experimental fishing with semi-floating shrimp traps took place between 65 to $400 \mathrm{~m}$ depth with considerable shrimp catches of the latter group (Plesionika narval and $P$. edwardsii) (Martins and Hargreaves 1991). A similar study conducted off Madeira from 1991 to 2008 with $P$. narval as a target indicated that semi-floating shrimp traps are more size- and speciesselective than benthic traps, catching larger shrimp and less by-catch, and suggesting that a fishery using these traps can be viable (Sousa et al. 2017). A commercial fishery using semi-floating shrimp traps targeting $P$. edwardsii is practised in the South Tyrrhenian Sea (Colloca 2002, Castriota et al. 2004). In the Canary
Islands, semi-floating shrimp traps were tested for the same species and a small-scale commercial operation was proposed (González et al. 1992). In 2012, experiments were conducted in the Canary Islands to study the viability of exploiting nektobenthic shrimps on a commercial basis using both traditional benthic traps and the new semi-floating type. The latter proved to be more efficient when targeting nektonic species such as Heterocarpus ensifer, P. edwardsii and P. naval (Arrasate-López et al. 2012). Despite the description of métiers in the Mediterranean and Atlantic, where $P$. edwardsii is targeted with traps, catch records are scarce. Catches for the western Mediterranean landed in Alicante are available between 1984 and 1991, with values of between 60 and 100 t per year (González et al. 1992).

Experimental fishing using semi-floating shrimp traps was carried out along the south and southwest coasts of Portugal during the summer of 2015 to investigate the possibility of catching the deep-water rose shrimp Parapenaeaus longirostris. These trials involved the deployment of 35 trap fleets with a total of 3533 traps and, despite the failure to capture $P$. longirostris, in some of the trials on the south coast significant amounts of shrimps of the genus Plesionika were caught. These shrimps, frequent in Mediterranean and Atlantic European waters (Vafidis et al. 2005), are common species in crustacean trawling and are occasionally landed because they are commercially valued (Monteiro et al. 2001). An average of $600 \mathrm{~kg}$ per year was landed by the Portuguese trawling fleet between 2010 and 2016 (information provided by DGRM).

In the present work, the utility of semi-floating shrimp traps to catch Plesionika edwardsii is discussed with a view to developing an additional fishery for the multi-gear fishing sector.

\section{MATERIALS AND METHODS}

The trap design and fleet rigging were adapted from Arrasate-López et al. (2012). The traps comprised two different sections, a cylinder and a conical section covered in a rigid polypropylene panel of rhomboid mesh $(15 \times 20 \mathrm{~mm})$ (Fig. 1A). A funnel-shaped opening at the base of the cylinder section allows the catch to enter and a small circular door topping the conical part enables the catch to be removed and/or the bait to be introduced in a small mesh bag placed inside the trap. A standard 1.5-m-long strap (linking the trap to the main line) and a pressure-resistant float are attached in opposite positions to the section where the cylinder and conical sections of the trap join, maintaining the traps sideways. The float provides buoyancy, while the length of the trap line controls the distance from the bottom, keeping the trap in a stable position (Fig. 1B). Four lines of traps, each with around 200 traps set $15 \mathrm{~m}$ apart and positioned $1.5 \mathrm{~m}$ off the bottom, were deployed and retrieved several times (typically once a day). The traps were baited with Atlantic mackerel (Scomber scombrus), a similar amount of bait being used in each trap. For the purpose of data analysis in this work, each deployment and retrieval of a single 


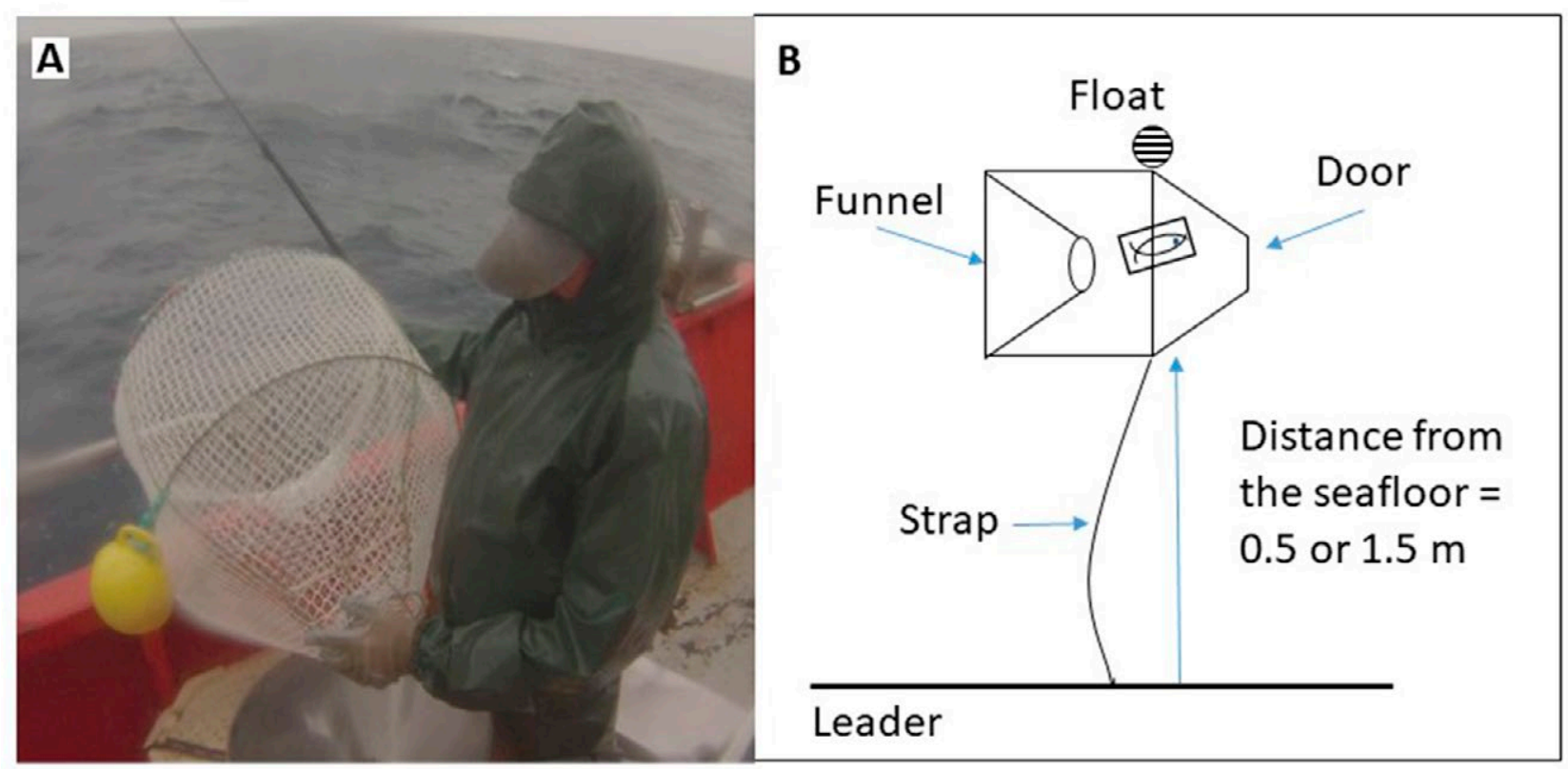

Fig. 1. - Semi-floating shrimp traps used in the experiment. A, photo of a trap; B, scheme of the trap and attachment to the main line.

line was considered a trial (14 trials were carried on while a member of the research team was onboard, of which 11 were sampled for the catch of individual traps).

The fishing vessel operated with a temporary licence to undertake experimental fishing, specifically to target nektobenthic shrimps. The operations were undertaken in fishing grounds inside the $12 \mathrm{~nm}$ line (territorial sea), during the annual closure period for crustacean trawlers, allowing for a safer deployment of trap fleets. The fleets were placed in two different areas: at the edge of the continental shelf off Lagos (Slope) and on the flanks of the Portimão Canyon (Canyon) (Fig. 2). A total of 11 trials were monitored in this study, carried out between 24 and 31 January at depths of 170 to $350 \mathrm{~m}$, corresponding to a total of 2102 observed traps (Table 1). The soaking time varied from 16 to 95 hours, longer times corresponding to fishing operations carried out over the weekend.

In two of the 11 trials, the basic setup was modified. The length of the straps was reduced in roughly half of the traps to maintain them about $0.5 \mathrm{~m}$ from the sea floor. In one of these trials, around $25 \%$ of the traps (including long and short straps) were left fishing without bait.

For each fishing operation, the total catch of Plesionika edwardsii (SSS) was weighed, and the number of shrimps in each trap was counted. For traps with a low number of SSS, an exact count was obtained. Otherwise, abundance was estimated in classes ranging from $5+$ to $50+$ in steps of five individuals. In some cases, both the estimation and the count were obtained to validate the estimate. Validation proved that the estimations were, on average, $5 \%$ below expected values. For the traps for which only estimated numbers were available, these values were multiplied by a factor of 1.05. All by-catch species were identified.

Data on the number of SSS per trap were used to study the effects of the factors bait (presence or absence) and distance from the seafloor (long $=1.5 \mathrm{~m}$ and short $=0.5 \mathrm{~m})$. These effects were addressed in two separate trials (trial 14 and trial 6, respectively)

Table 1. - General information for individual fishing trials (each corresponding to the deployment of a trap line): number of traps in each line, location, depth, starting date, starting time, duration (in hours and days), total catch of Plesionika edwardsii and catch per unit effort (CPUE)

\begin{tabular}{|c|c|c|c|c|c|c|c|c|c|}
\hline \multirow{2}{*}{ Trial } & \multirow{2}{*}{ Area } & \multicolumn{2}{|c|}{ Setting time } & \multirow{2}{*}{$\begin{array}{l}\text { Soaking time } 1 \\
\text { (hours) }\end{array}$} & \multirow{2}{*}{$\begin{array}{l}\text { Soaking time } 2 \\
\text { (days) }\end{array}$} & \multirow{2}{*}{$\begin{array}{l}\text { Average depth } \\
\text { (m) }\end{array}$} & \multirow{2}{*}{$\begin{array}{c}\text { Catch SSS } \\
(\mathrm{kg})\end{array}$} & \multirow[t]{2}{*}{$\mathrm{N}^{\mathrm{o}}$ of traps } & \multirow{2}{*}{$\begin{array}{l}\text { CPUE1 } \\
\mathrm{g} \mathrm{\operatorname {trap } ^ { - 1 }}\end{array}$} \\
\hline & & Day & Hour & & & & & & \\
\hline 1 & Slope & 24-gen & $14: 54$ & 20 & 1 & 331 & 35 & 186 & 188 \\
\hline 2 & Slope & 25-gen & $13: 37$ & 21 & 1 & 312 & 30 & 176 & 171 \\
\hline 3 & Slope & 24-gen & $12: 15$ & 27 & 1 & 347 & 32 & 207 & 155 \\
\hline 4 & Slope & 25-gen & $16: 32$ & 16 & 1 & 345 & 35 & 194 & 180 \\
\hline 5 & Canyon & 24 -gen & $18: 15$ & 23 & 1 & 289 & 30 & 190 & 158 \\
\hline 6 & Canyon ${ }^{\mathrm{a}, \mathrm{b}}$ & 25-gen & $20: 20$ & 22 & 1 & 177 & 35 & 193 & 181 \\
\hline 8 & Slope & 26-gen & $14: 15$ & 93 & 4 & 340 & 35 & 191 & 183 \\
\hline 9 & Slope & 26-gen & $16: 15$ & 94 & 4 & 346 & 25 & 202 & 124 \\
\hline 10 & Canyon & 26-gen & $20: 15$ & 95 & 4 & 258 & 40 & 183 & 219 \\
\hline 12 & Slope & 30-gen & $13: 29$ & 18 & 1 & 307 & 30 & 188 & 160 \\
\hline 14 & Canyon ${ }^{\mathrm{a}}$ & 30-gen & $20: 15$ & 18 & 1 & 277 & 35 & 192 & 182 \\
\hline
\end{tabular}

a Two levels of distance from the bottom were used: $1.5 \mathrm{~m}$ and $0.5 \mathrm{~m}$ from the bottom.

b $25 \%$ of the traps had no bait. 


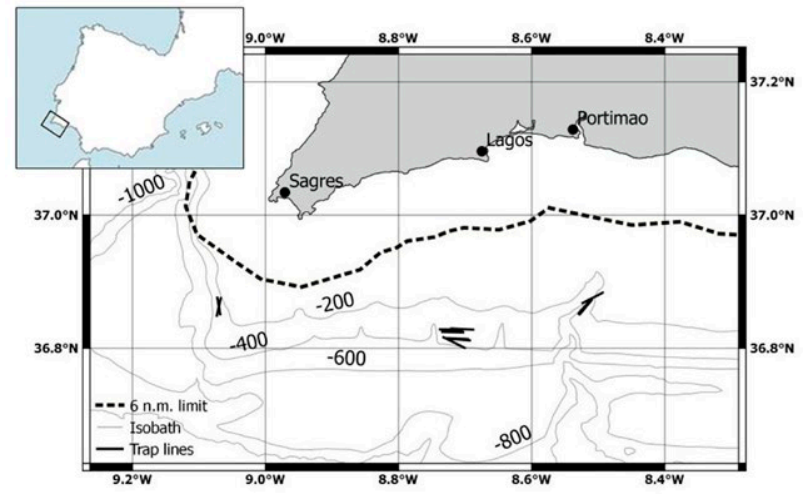

Fig. 2. - Map showing the two areas sampled with the position of the trap lines: off Lagos (Slope) and Portimão (Canyon).

in which bait presence and distance from the seafloor were modified from the basic setup. The significance of these factors was obtained using t-tests for independent samples.

Catch per unit effort (CPUE) was calculated for each fishing trial (corresponding to a trap line deployment) as the mean biomass of Plesionika per trap $\left(\mathrm{g} \mathrm{trap}^{-1}\right)$. The CPUE values were compared for the factors location (slope or canyon) and soaking (1 day vs 4 days soaking time) using a non-parametric Mann-Whitney test.

The net present value was used to evaluate economic viability. This a standard method for appraising long-term projects (Sutinen and Seijo 2018). Available values for average running costs, fixed costs and crew share predictors were adopted from a similar vessel (Leocádio et al. 2012) and updated to 2017 using the reported Harmonized Index of Consumer Prices for Portugal (EUROSTAT, overall index excluding energy and seasonal food). Diesel costs were updated based on fuel sale priced reported at PORDATA database (www. pordata.pt). The catch quantity and value (ex-vessel prices) were obtained from the fishing operations described in this work. The net present value analysis was calculated over a timeframe of ten years with an annual discount rate of $5 \%$.

\section{RESULTS}

The effect of trap distance from the bottom on the abundance of $P$. edwardsii, evaluated in trial 14, was not significant (n_short=101, n_long=91, p-value $=0.30$ ) while the presence of bait, evaluated in trial 6 , as expected, was highly significant (n_absent $=33$, n_present $=160$, p-value $<0.0001)$. The number of $P$.

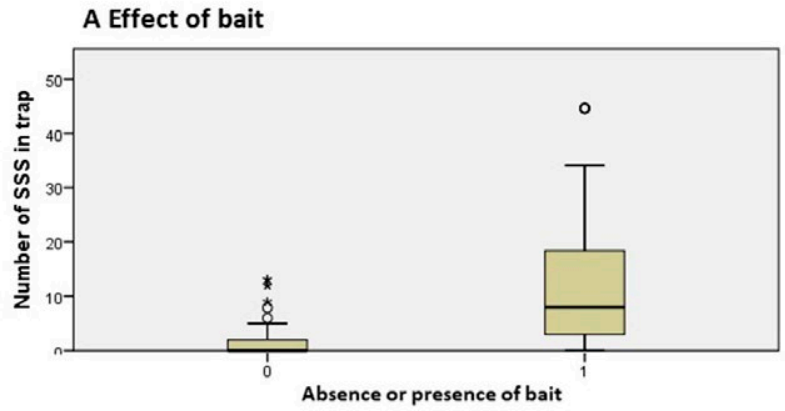

B Effect of distance from the bottom

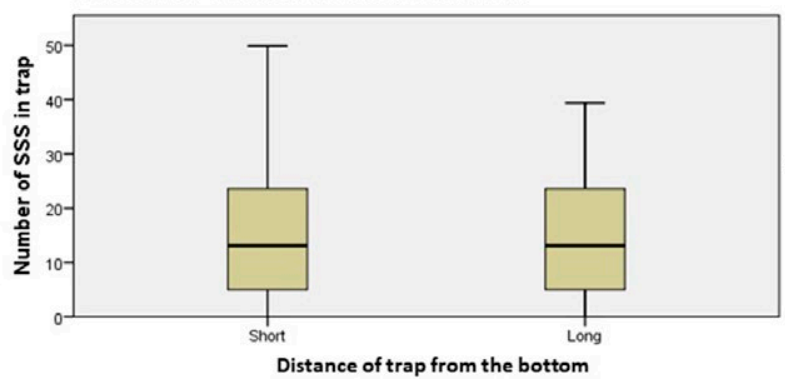

Fig. 3. - Box-plots representing the number of Plesionika edwardsii in individual traps as a function of: presence or absence of bait (n_present $=160, n \_$absent $=33$ ) $(\mathrm{A})$ and distance of the trap from the sea floor (B), long distance about $1.5 \mathrm{~m}$, short distance about $0.5 \mathrm{~m}$ (n_long=91, n_short=101).

edwardsii in traps with no bait was considerably lower (51\% of the traps empty with an average of 2 shrimps per trap) than that in the baited traps ( $8 \%$ empty with an average of 13 shrimps per trap). Box-plots for comparison of the levels of the factors DISTANCE from the seafloor and presence of BAIT are presented in Figure 3.

The results of the Mann-Whitney tests used to investigate the effect of the factors location (slope vs canyon) and soaking time (around 1 day vs around 4 days) on CPUE ( $\mathrm{g}$ of SSS trap ${ }^{-1}$ ) indicated no significant differences in both cases $(n=11, p$-values 0.39 and 0.54 , respectively). This suggests that the density of $P$. edwardsii is similar in both areas and that the catch is obtained during the first hours after deployment (up to around 1 day), likely when the bait attraction is acting, and no significant numbers of shrimp enter the traps after that period.

The by-catch (species and quantities) is presented in Table 2 . The only crustacean species caught alongside $P$. edwardsii were the rose shrimp (Parapenaeus longirostris) and the Norway lobster (Nephrops norvegicus). Fish by-catch was limited to the deep-sea sharks,

Table 2. - By-catch composition. Values in the table correspond to the total number of individuals of each by-catch species on each trap line.

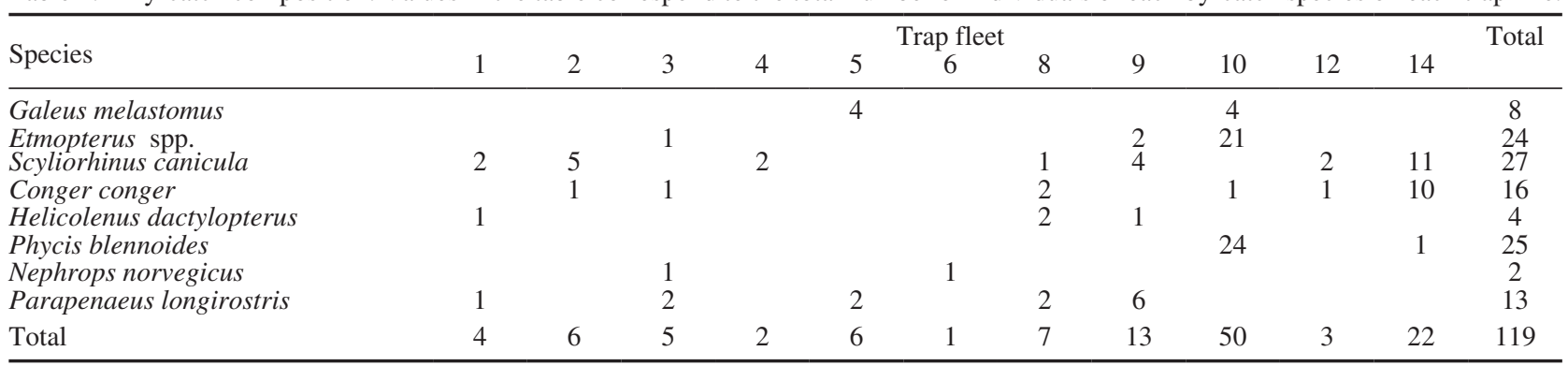


Table 3. - Data used for net present value analysis for the fishery of Plesionika edwardsii. Source: base values from Leocádio et al. (2012), updated by applying harmonised consumer price indexes from www.pordata.pt for diesel prices and Eurostat HCPI for all other costs.

\begin{tabular}{llc}
\hline Parameter values & Units & Value \\
\hline Price & $€$ per kg & 11.89 \\
Vessel utilization & Fishing days per year & 45 \\
Catch rate & Kg per fishing day & 79 \\
Average running costs & $€$ per fishing day & 470 \\
Fixed costs & $€$ per year & 13243 \\
Crew share & Proportion of net revenue & 0.5 \\
Taxes and social security & Proportion of gross revenue & 0.17 \\
Discount rate & Percent per year & $5 \%$ \\
\hline
\end{tabular}

Galeus melastomus, Etmopterus sp. and Scyliorhinus canicula, and three species of teleost fish (Conger conger, Helicolenus dactylopterus and Phycis blennoides). The by-catch was low despite higher values in two trials (10 and 14), both set in the flank of the Portimão Canyon.

Data from the ex-vessel sale (quantities and value) were obtained from the fish auction services. A total of eight landings were reported (landings at Sagres port and sales at Vila Real de Santo António fish auction), representing 19 days of vessel operations, corresponding to $1348 \mathrm{~kg}$ of $P$. edwardsii and revenue of 16032 Euros $\left(11.89 € \mathrm{~kg}^{-1}\right.$ and $79 \mathrm{~kg} \mathrm{day}^{-1}$ of the vessel at sea). The price for individual fish boxes ranged from 6.25 to $17.50 € \mathrm{~kg}^{-1}$.

The parameters for estimating net present value are indicated in Table 3. The economic net present value analysis points to a net negative revenue of -54741 euros in the first ten years $\left(5474 €\right.$ year $\left.^{-1}\right)$, but this situation can be inverted if the price $\mathrm{kg}^{-1}$ increases (switching value is $16.14 € \mathrm{~kg}^{-1}$ ).

\section{DISCUSSION}

The yield levels recorded for $P$. edwardsii in this study are similar in slope and canyon areas (165 and $185 \mathrm{~g} \mathrm{trap}^{-1}$ respectively), being higher than reported average values for experimental fisheries targeting the same species: 97 and $100 \mathrm{~g} \mathrm{trap}^{-1}$ in the South Tyrrhenian Sea (Colloca 2002, Sartor et al. 2006), and $108 \mathrm{~g} / \mathrm{trap} /$ day in the western Mediterranean (GarcíaRodríguez et al. 2000). Data from a commercial fishery in the western Mediterranean (González et al. 1992) covering a period of 12 years showed that yields of this species drop over time (from 175 to $200 \mathrm{~g} \mathrm{trap}^{-1}$ to 0 to $\left.51 \mathrm{~g} \mathrm{trap}^{-1}\right)$, suggesting the possibility that this is a species that can be easily overexploited (García-Rodríguez et al. 2000). In the central Mediterranean, catch fluctuations were also observed (varying between 27 and 97 t, Maynou and Cartes 2000).

The results suggest that the catch is obtained during the first day after deployment, with no significant loss of catch for longer soaking periods. This may offer the possibility of increasing catch rates by changing the bait type or the amount of bait in each trap. The fishing strategy can also be modified from the present experimental setup to increase the number of traps in the fleet and to investigate different distances among traps. These modifications have the potential of increasing the total catch, thus compensating for the added operation time, fuel consumption and workload. Improved gear-handling efficiency during onboard operations could also be sought to mitigate the costs mentioned above.

Growth studies for the Canary Islands (Santana et al. 1997, González et al. 2016), the western Mediterranean (Company and Sardá 2000) and the central Mediterranean (Tyrrhenian Sea) (Colloca 2002) suggest that $P$. edwardsii is a short-lived species, with maximum ages between 3 and 4 years (Colloca 2002, González et al. 2016), and subject to large inter-annual biomass oscillations depending on favourable environmental conditions (Maynou and Cartes 2000). The moderate commercial catches reported, and the potential for substantial fluctuations resulting from both exploitation and environmental factors, suggest that it is a resource that must be managed with a strict precautionary approach, limiting licences to a small number of vessels. A management strategy for this species may also require rotation of the fishing grounds exploited and imposition of annual catch limits.

The net present value analysis indicates a negative return on the investment based on the achieved catch rate and product value. However, this experimental fishing occurred in the worst period of the year regarding market potential. In January the deep-water trawling fleet fishing between 6 and $12 \mathrm{~nm}$ is not operating and the buyers of high-quality shrimp are not present at fish auctions. The ex-vessel value obtained (11.89 $\left.€ \mathrm{~kg}^{-1}\right)$ can be considerably improved either by selling during other months of the year or by establishing contracts with specific buyers. The expected limited catches may favour the last option. A simulation of annual average investment returns, changing the price per $\mathrm{kg}$ while keeping constant all other variables, shows that average values of 20,25 and $30 € \mathrm{~kg}^{-1}$ would generate average annual revenues of 5.0, 11.4 and 17.8 thousand euros, respectively. These prices may be compared with mean ex-vessel values for Plesionika species landed by the trawling fleet for the years 2010 to 2016, which varied between 18.90 and $29.73 €$ (the value for 2016 was $20.85 €$ ) (data provided by DGRM 2017).

\section{CONCLUSION}

The shrimp P. edwardsii may be a valuable resource for the multi-gear fishing fleet off the Algarve coast. Its exploitation is particularly attractive due to the species' association with steep flanks, which can be fished by static gears all year around even when the trawling fleet is active. Due to the limitation in the fishing resource and competition with other, more profitable crustacean fisheries, semi-floating shrimp traps can only be a complementary fishery activity for a small number of multi-gear vessels.

Future studies should be directed towards the biology of Plesionika shrimps, such as its distribution, growth rate and recruitment variability, offering the possibility of developing multi-gear fisheries that are well-adapted to the capture of the adult populations of these species. 


\section{ACKNOWLEDGEMENTS}

The authors would like to acknowledge the contribution of Dr Marian Torres and Dr Catia Bartilotti for their assistance with species identification, the owners and land personnel of the fishing company Ao Longo do Tempo, and the crews of Pirata do Mar and Mar Vermelho for providing invaluable help. This research was supported by the H2020 REA 634495-MINOUW Project.

\section{REFERENCES}

Arrasate-López M., Tuset V.M., Santana J.I., et al. 2012. Fishing methods for sustainable shrimp fisheries in the Canary Islands (North-West Africa). Afr. J . Mar. Sci. 34: 331-339. https://doi.org/10.2989/1814232X.2012.725281

Borges T., Erzini K., Bentes L., et al. 2001. By-catch and discarding practices in five Algarve (southern Portugal) métiers. J. Appl. Ichthyol. 17: 104-114. https://doi.org/10.1111/j.1439-0426.2001.00283.x

Campos A., Fonseca P., Fonseca T., et al. 2007. Definition of fleet components in the Portuguese bottom trawl fishery. Fish. Res. 83: $185-191$. https://doi.org/10.1016/j.fishres.2006.09.012

Castriota L., Falautano M., Romeo T., et al. 2004. Crustacean fishery with bottom traps in an area of the southern Tyrrhenian Sea: species composition, abundance and biomass. Mediterr. Mar. Sci. 5: $15-22$. https://doi.org/10.12681/mms.199

Colloca F., 2002. Life cycle of the deep-water pandalid shrimp Plesionika edwardsii (Decapoda, Caridea) in the central Mediterranean Sea. J. Crustac. Biol. 22: 775-783. https://doi.org/10.1163/20021975-99990291

Company J., Sardá F. 2000. Growth parameters of deep-water decapod crustaceans in the Northwestern Mediterranean Sea: a comparative approach. Mar. Biol. 136: 79-90. https://doi.org/10.1007/s002270050011

Costa E., Erzini K., Borges T. 2008. Bycatch of crustacean and fish bottom trawl fisheries from southern Portugal (Algarve). Sci. Mar. 72: 801-814. https://doi.org/10.3989/scimar.2008.72n4801

Direção-Geral de recuroso Naturais, Segurança e Serviços Marítimos (DGRM). 2017. Recursos da Pesca. Série Estatística, Vol. 29 A-B, Ano 2016. Direção-Geral de recuroso Naturais, Segurança e Serviços Marítimos, Lisboa, julho 2017, 182 pp.

Fonseca P., Campos A., Mendes B., et al. 2005. Potential use of a Nordmøre grid for by-catch reduction in a Portuguese bottomtrawl multispecies fishery. Fish. Res. 73: 49-66. https://doi.org/10.1016/j.fishres.2005.01.005

Fonseca P., Campos A., Millar R.B. 2007. Codend selection in the deep-water crustacean trawl fishery in Portuguese southern waters. Fish. Res. 85: 49-60. https://doi.org/10.1016/j.fishres.2006.11.036

Gage J.D., Roberts J.M., Hartley J.R., et al. 2005. Potential impacts of deep-sea trawling on the benthic ecosystem along the Northern European continental margin: A review. In: Barnes B.W., Thomas J.P. (eds), Benthic Habitats and the Effects of Fishing, Am. Fish. Soc. Symp. 41: 503-517.

García-Rodríguez M., Esteban A., Gil J.P. 2000. Considerations on the biology of Plesionika edwardsi (Brandt, 1851) (Decapoda,
Caridea, Pandalidae) from experimental trap catches in the Spanish western Mediterranean Sea. Sci. Mar. 64: 369-379. https://doi.org/10.3989/scimar.2000.64n4369

González J.A., Carrillo J., Santana J., et al. 1992. La pesquería de quisquilla, Plesionika edwardsii (Brandt, 1851), con tren de nasas en el Levante español. Ensayos a pequeña escala en Canarias. Inf. Téc. Sci. Mar. 170: 3-31.

González J.A., Pajuelo J.G., Triay-Portella R., et al. 2016. Latitudinal patterns in the life-history traits of three isolated Atlantic populations of the deep-water shrimp Plesionika edwardsii (Decapoda, Pandalidae). Deep-Sea Res. Pt II 117: 28-38. https://doi.org/10.1016/j.dsr.2016.09.004

Jones J. 1992. Environmental impact of trawling on the seabed: a review. New Zeal. J. Mar. Fresh. 26: 59-67. https://doi.org/10.1080/00288330.1992.9516500

Leocádio A.M., Whitmars D., Castro M. 2012. Comparing trawl and creel fishing for Norway lobster (Nephrops norvegicus): Biological and economic considerations. PLoS ONE 7: e39567. https://doi.org/10.1371/journal.pone.0039567

Martín J., Puig P., Masqué P., et al. 2014. Impact of bottom trawling on deep-sea sediment properties along the flanks of a submarine canyon. PLoS ONE 9: e104536. https://doi.org/10.1371/journal.pone.0104536

Martins H., Hargreaves P. 1991. Shrimps of the families Pandalidae and Hippolytidae (Crustacea: Decapoda) caught in benthic traps off the Azores. Arquipélago 9: 47-61.

Maynou F., Cartes J. 2000. Community structure of bathyal decapod crustaceans off south-west Balearic Islands (western Mediterranean): seasonality and regional patterns in zonation. J. Mar. Biol. Assoc. UK 80: 789-798. https://doi.org/10.1017/S0025315400002769

Monteiro P., Araújo A., Erzini K., et al. 2001. Discards of the Algarve (southern Portugal) crustacean trawl fishery. Hydrobiologia 449: 267-277. https://doi.org/10.1023/A:1017575429808

Oberle F.K., Storlazzi C.D., Hanebuth T.J. 2015. What a drag: Quantifying the global impact of chronic bottom trawling on continental shelf sediment. J. Mar. Syst. 159: 109-119. https://doi.org/10.1016/j.jmarsys.2015.12.007

Roberts C.M. 2002. Deep impact: the rising toll of fishing in the deep sea. Trends Ecol. Evol. 17: 242-245. https://doi.org/10.1016/S0169-5347(02)02492-8

Santana J.I., González J.A., Lozano I.J., et al. 1997. Life history of Plesionika edwardsii (Crustacea, Decapoda, Pandalidae) around the Canary Islands, Eastern Central Atlantic. S. Afr. J. Mar. Sci. 18: 39-48. https://doi.org/10.2989/025776197784161045

Sartor P., Rossetti I., Vannucci A., et al. 2006. Pesca del gobbetto striato, Plesionika edwardsii (Brandt, 1851), con nasse sperimentali nel Tirreno Settentrionale. Biol. Mar. Medit. 13: 288-289.

Sousa R., Pinho M.R., Delgado J., et al. 2017. Prospective study of the fishery of the shrimp Plesionika narval (Fabricius, 1787) in the Northeastern Atlantic. Braz. J. Biol. 77: 585-593. https://doi.org/10.1590/1519-6984.21015

Sutinen J., Seijo J.C. 2018. Theory, policy and contemporary challenges for bioeconomics. In: Seijo J.C., Sutinen J. (eds), Advances in Fisheries Bioeconomics: Theory and Policy. Routledge, Taylor and Francis, pp. 186-190.

Vafidis D., Politou C., Carbonell A., et al. 2005. A review of the biology and fisheries of the genus Plesionika Bate, 1888 (Decapoda, Caridea, Pandalidae) in European waters. Crustaceana 78: 335-352.

https://doi.org/10.1163/1568540054286592 